\title{
抗アレルギー薬 1-(2-Ethoxyethyl)-2-(hexahydro-4-methyl-
}

\section{$1 \boldsymbol{H}$-1, 4-diazepin-1-yl)-1 $\boldsymbol{H}$-benzimidazole Difumarate （KG-2413）のラットおよびモルモットにおける代謝}

\author{
和田 幸雄, 高橋 秀之, 浜田司, 酒井 孝範 \\ 川島 恒男, 粟田 則男

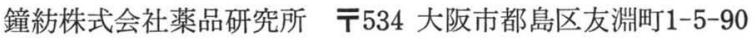

\begin{abstract}
Key words : 1 -(2-Ethoxyethyl)-2-(hexahydro-4-methyl-1 $H$-1,4-diazepin-1-yl)- $1 H$ benzimidazole difumarate (KG-2413), Antiallergic agent, Metabolism, Excretion, Interspecies difference, Rat, Guinea pig
\end{abstract}

\section{Metabolism of an antiallergic Agent, 1-(2-Ethoxyethyl)-2- (hexahydro-4-methyl-1 $\mathrm{H}$-1, 4-diazepin-1-yl)- $1 \mathrm{H}$ - benzimidazole Difumarate (KG-2413), in Rats and Guinea Pigs}

Yukio WAdA, Hideyuki TAKahashi, Tsukasa HAMAdA, Takanori SAKAI, Tsuneo Kawashima and Norio Awata

Pharmaceuticals Research Center, Kanebo, Ltd., 5-90, Tomobuchi-cho 1-chome, Miyakojima-ku, Osaka 534, Japan

\section{Summary}

The metabolism of an antiallergic agent, 1-(2-ethoxyethyl)-2-(hexahydro-4methyl-1H-1,4-diazepin-1-yl)-1H-benzimidazole difumarate (KG-2413), was studied in rats and guinea pigs after oral administration of the ${ }^{14} \mathrm{C}$ labelled compound.

KG-2413 and its metabolites in the urine, bile, plasma and liver of rats were quantified. The major metabolites of KG-2413 in rats were 5-hydroxylated compound (M 5 b), 6-hydroxylated compound (M 5 a) and their conjugated metabolites. Tracer concentration of the unchanged drug was found, so it was assumed that KG-2413 was rapidly metabolized in rats.

The urinary metabolites in guinea pigs were also quantified. The major metabolite was $N$-oxide compound (M 9), and $\mathrm{M} 5 \mathrm{a}$ and $\mathrm{M} 5 \mathrm{~b}$ were present mostly as conjugated metabolites, but the amounts of them were about one sixth of M9. The urinary excretion of the unchanged drug in guinea pigs was higher than that in rats.

There were remarkable interspecies differences in the urinary excretion of the metabolites after oral administration of KG-2413. 


\section{緒 言}

1-(2-Ethoxyethyl)-2-(hexahydro-4-methyl$1 H$-1,4-diazepin-1-yl)-1H-benzimidazole difumarate (KG-2413) は, Fig. 1 飞示す化学構造 を有し, 強い抗ヒスタミン作用並びにヶミカルメ ディエーター遊離抑制作用を示す新規な抗アレル ギー薬であり，また，副作用が少ないことが知ら れている ${ }^{1 \sim 4}$. KG-2413 の体内動態については, ラット，モルモットおよびイヌで詳細な検討が行

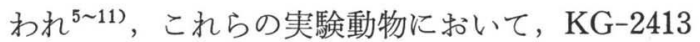
は消化管から良好に吸収されること, 活発な胆汁 排泄之腸肝循環が認められること, 打よび未変化 体の血漿中挙動から KG-2413 の生物学的利用率 に種差があることが明らかとされている。また， KG-2413 の代謝様式として，a）ベンズイミダ ゾール環の 5 位または 6 位の水酸化，b ） 1,4-ジ アゼピン環の 4 位の窒素の $N$-酸化㧊よび $N$-脱 メチル化，ｃ） 1,4-ジアゼピン環の $\alpha$-炭素の酸 化 (ラクタム形成) および d) 側鎖の脱エチル化 などが明らかとなり, これらが単独あるいは逐次 的に起こった代謝物が，ラット尿特よび胆汁中よ り単離同定されている ${ }^{12)}$. 本研究では, ラット尿, 胆汁, 血漿掞よび肝臓中代謝物の定量を行い, 代 謝経路の推定を行った。 また, モルモット尿中代 謝物についても定量を行い, 種差について検討を 加えた.

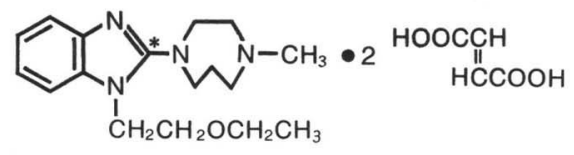

Fig. 1. Structure of $\mathrm{KG}-2413-{ }^{-14} \mathrm{C}$ * : labelled position with ${ }^{14} \mathrm{C}$

\section{実験材料および実験方法}

\section{1. 使用薬物}

$\mathrm{KG}-2413-{ }^{14} \mathrm{C}$ は, 当研究室にて合成されたも のを使用した ${ }^{13)}$. その比放射能は, 2.00 または $2.01 \mathrm{GBq} / \mathrm{mmol}(54.0$ または $54.4 \mathrm{mCi} / \mathrm{mmol})$ であった， KG-2413 は前報5) と同一のものを用 いた，KG-2413 の代謝物合成標品である 1-(2ethoxyethyl)-2-(hexahydro-4-methyl-1H-1, 4diazepin-1-yl)-5-hydroxy-1H-benzimidazole, 1-(2-ethoxyethyl)-2-(hexahydro-4-methyl$1 H$-1,4-diazepin-1-yl)-6-hydroxy-1 $H$-benzimidazole, 1-(2-ethoxyethyl)-2-(hexahydro-4methyl-1H-1, 4-diazepin-1-yl)-1 $H$-benzimidazole $N$-oxide, 1-(2-ethoxyethyl)-2-(hexahydro - $1 H$-1,4-diazepin-1-yl)- $1 H$-benzimidazole, 2(hex ahydro-4-methyl-1H-1,4-diazepin-1-yl)1-(2-hydroxyethyl)-1H-benzimidazole は当研 究所にて合成した ${ }^{14)}$. その他の試薬は，いずれも 市販の試薬特級を和光純薬工業(秼より購入した.

\section{2. 実験動物}

雄性 Wistar 系ラット (specific pathogen free, 体重 200 260 g）拈よび雄性 Hartley 系モルモ ット（体重 330～370 g）を静岡県実験動物農業協 同組合より購入した。 ラットおよびモルモット は, 恒温恒湿下 $\left(22 \pm 1^{\circ} \mathrm{C}, 55 \pm 5 \%\right)$ で 1 週間以 上予備飼育した後, 薬物投与前 $20 \sim 24$ 時間絶食し て使用した。な招胆汁を採取する際には，投与直 前に軽いエーテル麻酔下で常法に従って胆管にカ ニューレを施した。䬲 (CE-2 または $\mathrm{CE}-4$, 日 本クレア(秼) $)$ は薬物投与後 6 時間以降, 通常通り 与えた。なお，試験期間中水は自由に与えた。

\section{3. 投与液の調製および投与方法}

投与液は， $\mathrm{KG}-2413-{ }^{14} \mathrm{C}$ に非標識 $\mathrm{KG}-2413$ を加光, ラットでは $0.4 \mathrm{mg} / 0.74 \mathrm{MBq}(20 \mu \mathrm{Ci}) /$ $\mathrm{m} l$ となるように，モルモットでは $0.6 \mathrm{mg} / 0.56$ $\mathrm{MBq}(15 \mu \mathrm{Ci}) / \mathrm{m} l$ となるように生理食塩液を加 光溶解, 調製した. ラットでは $1 \mathrm{mg} / 1.85 \mathrm{MBq}$ $(50 \mu \mathrm{Ci}) / \mathrm{kg}$ の, モルモットでは $2 \mathrm{mg} / 1.85 \mathrm{MBq}$ $(50 \mu \mathrm{Ci}) / \mathrm{kg}$ の投与量で，胃ゾンデを用いて強制 的に胃内に注入した.

\section{4. 尿, 胆汁, 血漿および肝臓の採取}

薬物投与後ラット特よびモルモットは, 代謝ヶ ージにて個別に飼育し, 投与後24時間までに排泄 された尿を採取した．胆管にカニューレを施した ラットは, 投与後ボールマンケージに固定し，投 与後24時間までの胆汁を採取した。また，ラット 血漿および肝臓を得る際には, 投与後所定時間に エーテル麻酔下開腹し, 腹下大静脈よりヘパリン 処理した注射筒を用いて採血した後，肝蔵を摘出 した。血液は直ちに遠心分離 $(3,000 \mathrm{rpm}, 10$ 分 間）し，血漿を得た。 


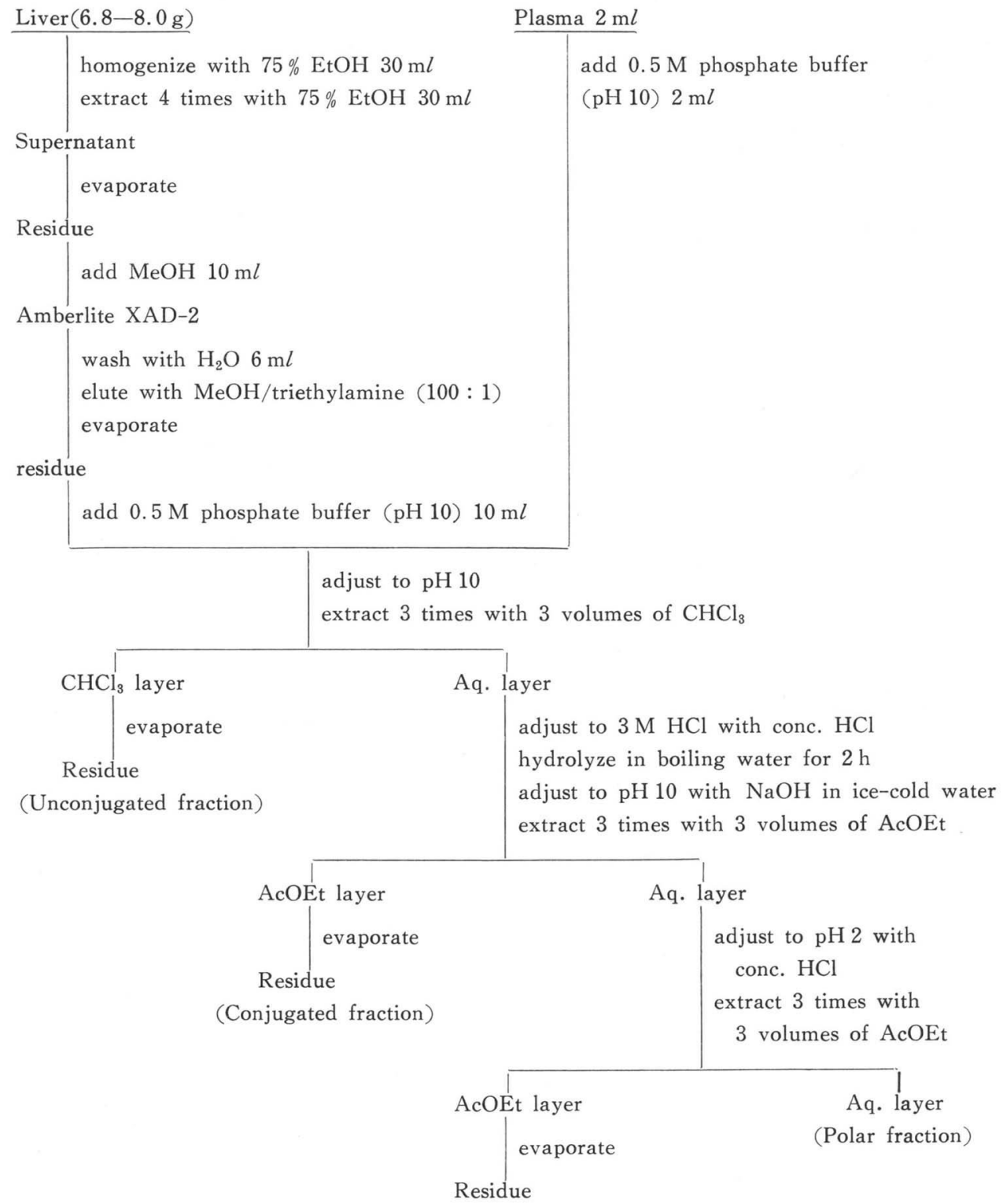

(Acidic fraction)

Scheme 1. Procedure for the fractionation of the metabolites in plasma and liver

\section{5. 試料の分画}

尿特よび胆汁中の代謝物は, 前報 ${ }^{12)}$ の方法に 従って分画した.

血漿忬よび肝鐵は Scheme 1 と示す方法に従 って, 非抱合体画分, 抱合体画分, 酸性画分和上 び極性画分に分画した．各画分中の放射能を測定 するとともに，非抱合体画分和よび抱合体画分の 一部, あるいは全量を代謝物の合成標品とともに 薄層クロマトグラフィー（TLC）に供し，オート
ラジオグラム (TLC-ARG) を作成した.

\section{TLC-ARG の作成}

市販のシリカゲルプレート (Pre-coated Kieselgel $60 \mathrm{~F}_{254}, 20 \times 20 \mathrm{~cm}$, 厚さ $0.25 \mathrm{~mm}$, Merck) を用い, 一次溶媒：ジクロロメタン/メタノール/ $25 \sim 28 \%$ アンモ二ア水 $(40: 9: 1, \mathrm{v} / \mathrm{v})$, 二次溶 媒: nーブタノール $/ 25 \sim 28 \%$ アンモニア水 $(5: 1$, $\mathrm{v} / \mathrm{v})$ で二次元に展開した. 展開後, TLC の板を 工業用X線フィルム (Fuli X-ray film Ix, 25.4 
$\times 30.5 \mathrm{~cm}$ ，富士写真フィルム䛈) $に$ に 74 日間 密着させ, TLC-ARGを作成した。

\section{7. 代謝物の定量}

UV (254 nm) 照射により TLC 上の代謝物標 品の位置を確認後, 各代謝物に相当する部分拈よ び TLC-ARG の黑化部位のシリカゲルをかき取 った.シリカゲルはよく粉砕後バイアル瓶に入 れ, メタノール/トリェチルアミン (100:1)を 1 ないし $2 \mathrm{~m} l$ 加えて10分間超音波処理した後,

Scintisol ${ }^{\circledR} \mathrm{EX}-\mathrm{H}$ (侏同仁化学研究所) $12 \mathrm{~m} l$ を 加光て放射能を測定した.

\section{8. 放射能の測定}

尿特よび胆汁中放射能の測定は, 前報 ${ }^{12)}$ の方 法に従った.

肝臓 $(6.8 \sim 8.0 \mathrm{~g})$ は, あらかじめ水冷した約 $30 \mathrm{ml}$ の $75 \%$ エタノール溶液とともにヒスコトロ ンを用いて懸濁した後一定用量とした。肝臓懸濁 液 $50 \mu l$ または血漿 $30 \mu l$ に, それぞれ水 $1 \mathrm{~m} l$ 特よび Scintisol ${ }^{\circledR} \mathrm{EX}-\mathrm{H} 12 \mathrm{~m} l$ を加兄, 測定試 料とした. 放射能の測定は, 液体シンチレーショ ンカウンター (Packard, model B-2450) により 行った。

\section{結 果}

\section{1. ラット尿中代謝物の定量}

前報 ${ }^{12)}$ にて 報告したよらに，ラットに $\mathrm{KG}-$ $2413-{ }^{14} \mathrm{C}$ を $1 \mathrm{mg} / \mathrm{kg}$ 経口投与後 24 時間までの尿 $(24.5 \pm 3.3 \%$ of dose) を溶媒分画した結果, 放 射能は主に抱合体 $(54.7 \pm 8.0 \%$ of urine $)$ とし て排泄される。 また, 非抱合体も尿中排泄量の約 $1 / 4(23.5 \pm 3.6 \%$ of urine) を占める. さらに非 抱合体画分の TLC-ARG では, KG-2413 遊離 塩基 (未変化体) のスポットのほかに, 約14種の 放射性スポットが，抱合体画分の TLC-ARG で は約 6 種の放射性スポットが認められ, その大部 分が単離同定されている.

そこで, これら非抱合体画分拉よび抱合体画分 中の未変化体物よび代謝物（M 1-M 12 a,b) につ いて定量を行い，その結果を投与量に対する割合 で Table I に示した. 非抱合体画分では, M 5 a および M 5 b の両水酸化体が最も多く検出さ れ, 未変化体の排泄量はごく僅かであった。一 方, 抱合体画分では, M $5 \mathrm{~b}$ が最も多く検出され,
Table I. Urinary excretion of KG-2413 and its metabolites after oral administration of $\mathrm{KG}-2413-{ }^{14} \mathrm{C}$ in rats

\begin{tabular}{lcc}
\hline \hline \multirow{2}{*}{ Metabolites } & \multicolumn{2}{c}{ Urinary excretion (\% of dose) } \\
\cline { 2 - 3 } & Unconjugated & Conjugated \\
\hline KG-2413 base & $0.10 \pm 0.02$ & N.D. \\
M1 & $0.08 \pm 0.02$ & N.D. \\
M2 a b & $0.13 \pm 0.04$ & N.D. \\
M3, & $0.45 \pm 0.03$ & N.D. \\
M5 a & $2.07 \pm 0.54$ & $1.21 \pm 0.56$ \\
M5 b & $1.43 \pm 0.44$ & $8.23 \pm 1.69$ \\
M6 & $0.09 \pm 0.01$ & N.D. \\
M7 & $0.34 \pm 0.04$ & N.D. \\
M8 & $0.08 \pm 0.00$ & N.D. \\
M9 & $0.07 \pm 0.01$ & N.D. \\
M10 a , b & $0.15 \pm 0.05$ & $0.08 \pm 0.03$ \\
M11 a , b & $0.03 \pm 0.01$ & $0.16 \pm 0.02$ \\
M12 a & $0.02 \pm 0.00$ & $0.20 \pm 0.07$ \\
M12 b & $0.03 \pm 0.01$ & $2.05 \pm 0.50$ \\
\hline
\end{tabular}

Each value represents the mean \pm S. D. of four animals.

N.D. : not detectable

Table II. Biliary excretion of KG-2413 and its metabolites after oral administration of $\mathrm{KG}-2413-{ }^{-14} \mathrm{C}$ in bile-duct-cannulated rats

\begin{tabular}{cc}
\hline \hline & $\begin{array}{c}\text { Biliary excretion } \\
(\% \text { of dose })\end{array}$ \\
\cline { 2 - 2 } Metabolites & Conjugated \\
\hline KG-2413 base & N.D. \\
M2 a , b & $0.93 \pm 0.06$ \\
M3, 4 & N. D. \\
M5 a & $10.01 \pm 0.59$ \\
M5 b & $36.68 \pm 3.02$ \\
M6 & N.D. \\
M7 & N.D. \\
M8 & N.D. \\
M9 & N.D. \\
M10 a & $1.66 \pm 0.25$ \\
M10 b & $1.70 \pm 0.14$ \\
M11 a & $1.14 \pm 0.07$ \\
M11 b & $0.55 \pm 0.15$ \\
M12 a , b & $0.31 \pm 0.03$ \\
\hline
\end{tabular}

Each value represents the mean $\pm S$. D. of four animals.

N.D. : not detectable 
次いで, M 12 b および M 5 a が比較的多く認め られた。

\section{2. ラット胆汁中代謝物の定量}

前報 ${ }^{12)}$ で示したように，ラットに KG-2413${ }^{14} \mathrm{C}$ を $1 \mathrm{mg} / \mathrm{kg}$ 経口投与後 24 時間までの放射能 の胆汁排泄率は, 投与量の $89.4 \pm 5.8 \%$ を占める. また，放射能は主に抱合体 $(65.6 \pm 1.3 \%$ of bile) として存在し, 非抱合体画分 $(2.8 \pm 0.7 \%$ of bile) はごく僅かである.さらに抱合体画分の TLCARG では，放射性代謝物として約 8 種のスポッ トが認められている.

そこで，抱合体画分中代謝物について定量を行 い，その結果を投与量に対する割合で Table II に示した，胆汁中では，M5 a および M 5 b の 両水酸化体が抱合体として最も多く認められた。

\section{3. ラット血漿中代謝物の定量}

ラットに $\mathrm{KG}-2413-{ }^{-14} \mathrm{C}$ を $1 \mathrm{mg} / \mathrm{kg}$ 経口投与. 後の血漿を, Scheme 1 に示した操作に従い溶媒
分画したそその結果を Table III に示した. 放射 能の最高血漿中濃度到達時間 $(10 \sim 15 \text { 分 })^{6)}$ に特 いて, 血漿中放射能は主として抱合体として存在 した、また, 各画分の比率を前述の 24 時間尿の結 果 ${ }^{12)}$ と比較すると, 抱合体画分は尿とほぼ同様 であり,また，非抱合体画分も尿より僅かに低い 程度であった. 投与後60分でも, 各画分の比率に 顕著な変化は認められなかったが, 放射能の第 2 のピークが認められる投与後 6 時間 ${ }^{6)}$ では, 非抱 合体画分の占める割合が急激に減少し, ほとんど が抱合体として存在した.

次に 1 例として, 投与後15分の血漿の非抱合体 画分および抱合体画分の TLC-ARG の模式図を Fig. 2 に示した. 非抱合体画分では未変化体以 外に放射性代謝物として約10種の, 抱合体画分で は約 5 種のスポットが認められた.

また，投与後15分和よび60分の非抱合体および 抱合体画分中の代謝物を定量した結果を Table

Table III. Plasma levels and fractionation of radioactivities in the plasma after oral administration of $\mathrm{KG}-2413-{ }^{-14} \mathrm{C}$ in rats

\begin{tabular}{rcrcrc}
\hline \hline \multirow{2}{*}{$\begin{array}{c}\text { Time } \\
(\mathrm{min})\end{array}$} & $\begin{array}{c}\text { Plasma level } \\
\left(\begin{array}{l}\text { ng equivalent to } \\
\mathrm{KG}-2413 \text { base } / \mathrm{m} l\end{array}\right)\end{array}$ & Unconjugated & Conjugated & Acidic & Polar \\
\cline { 3 - 6 } & $72.28 \pm 20.77$ & $16.1 \pm 2.03$ & $60.4 \pm 3.84$ & $0.3 \pm 0.06$ & $17.7 \pm 0.32$ \\
15 & $26.47 \pm 6.88$ & $14.8 \pm 3.14$ & $56.7 \pm 3.09$ & $0.4 \pm 0.15$ & $19.1 \pm 2.74$ \\
60 & $22.90 \pm 4.25$ & $2.6 \pm 0.42$ & $85.4 \pm 2.00$ & $0.2 \pm 0.28$ & $11.1 \pm 5.26$ \\
360 & & &
\end{tabular}

Each value represents the mean \pm S. D. of three animals.
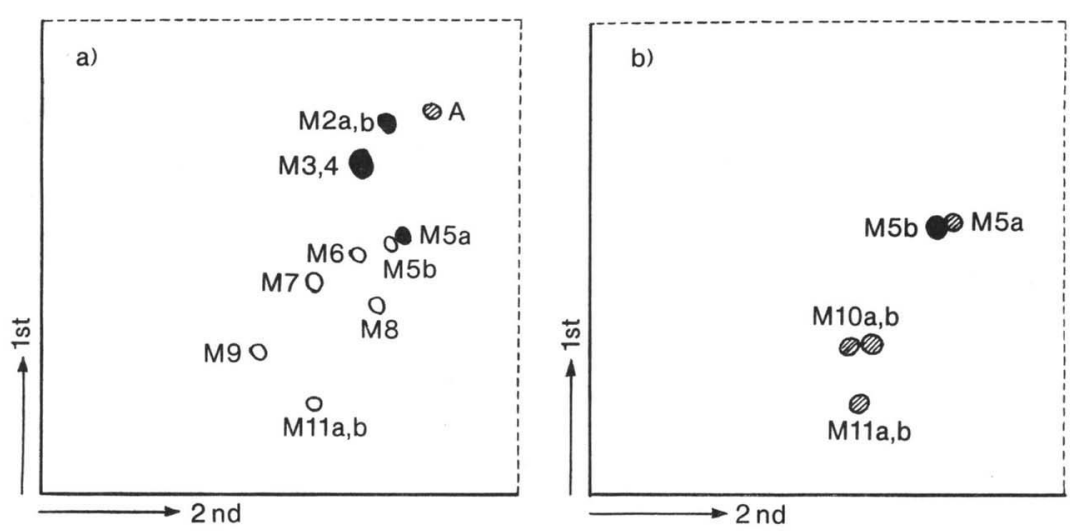

Fig. 2. Autoradiograms of the two-dimensional TLC of the metabolites extracted from plasma sample collected 15 min after oral administration of KG-2413${ }^{14} \mathrm{C}$ in rats

a) Unconjugated fraction, b) Conjugated fraction

A : KG-2413 base 
Table IV. Quantification of KG-2413 and its metabolites in the plasma after oral administration of $\mathrm{KG}-2413-{ }^{14} \mathrm{C}$ in rats

\begin{tabular}{|c|c|c|c|c|c|}
\hline \multirow{3}{*}{ Metabolites } & \multicolumn{5}{|c|}{$\%$ of plasma } \\
\hline & \multicolumn{2}{|c|}{$15 \mathrm{~min}$} & \multicolumn{2}{|c|}{$60 \mathrm{~min}$} & \multirow{2}{*}{$\frac{360 \mathrm{~min}}{\text { Conjugated }}$} \\
\hline & Unconjugated & Conjugated & Unconjugated & Conjugated & \\
\hline KG-2413 base & $0.61 \pm 0.07$ & N.D. & $0.67 \pm 0.08$ & N.D. & N.D. \\
\hline $\mathrm{M} 2 \mathrm{a}, \mathrm{b}$ & $2.48 \pm 0.42$ & N.D. & $4 \cdot 26 \pm 1 \cdot 14$ & N.D. & N.D. \\
\hline M3,M4 & $3.25 \pm 0.15$ & N.D. & $2.38 \pm 0.48$ & N.D. & N.D. \\
\hline M5 a & $1.32 \pm 0.19$ & $8.23 \pm 2.76$ & $1.05 \pm 0.33$ & $7.66 \pm 1.03$ & $7.46 \pm 1.24$ \\
\hline M5 b & $0.37 \pm 0.10$ & $33.99 \pm 1.92$ & $0.31 \pm 0.05$ & $30.91 \pm 3.28$ & $62.16 \pm 2.45$ \\
\hline M6 & $0.30 \pm 0.04$ & N.D. & $0.29 \pm 0.12$ & N.D. & N.D. \\
\hline M7 & $0.43 \pm 0.12$ & N.D. & $1.14 \pm 0.33$ & N.D. & N.D. \\
\hline M8 & $0.15 \pm 0.01$ & N.D. & $0.13 \pm 0.04$ & N.D. & N. D. \\
\hline M9 & $0.33 \pm 0.05$ & N.D. & $0.22 \pm 0.08$ & N.D. & N.D. \\
\hline M10 a , b & N.D. & $4.41 \pm 1.15$ & N.D. & $3.81 \pm 0.50$ & N. D. \\
\hline M11 a , b & $0.35 \pm 0.03$ & $1.99 \pm 0.92$ & N.D. & $5.25 \pm 0.47$ & N.D. \\
\hline M12 a, b & N.D. & N.D. & N.D. & N.D. & $1.59 \pm 0.34$ \\
\hline
\end{tabular}

Each value represents the mean $\pm \mathrm{S}$. D. of three animals.

N.D. : not detectable

Table V. Liver levels and fractionation of radioactivities in the liver after oral administration of $\mathrm{KG}-2413-{ }^{14} \mathrm{C}$ in rats

\begin{tabular}{rccccc}
\hline \hline \multirow{2}{*}{$\begin{array}{c}\text { Time } \\
(\text { min })\end{array}$} & $\begin{array}{c}\text { Liver level } \\
(\% \text { of dose })\end{array}$ & Unconjugated & Conjugated & Acidic & Polar \\
\cline { 3 - 6 } & $21.95 \pm 3.22$ & $38.4 \pm 3.44$ & $43.8 \pm 2.62$ & $0.5 \pm 0.00$ & $19.3 \pm 2.54$ \\
15 & $6.18 \pm 1.42$ & $47.2 \pm 5.23$ & $28.3 \pm 3.76$ & $1.0 \pm 0.06$ & $23.5 \pm 2.95$ \\
60 & $1.44 \pm 0.05$ & - & - & - & - \\
360 & & - & & -
\end{tabular}

Each value represents the mean $\pm S$. D. of three animals.

- : not tested

IV に示した．非抱合体画分では，M 2 a,b, M 3 または M 4 (M 4 は未同定) に相当する代謝物 执よび M 5 a が多く検出され, また, 投与後 60 分では M7 も多く認められた. 一方, 抱合体画 分では, M 5 b が最も多く検出され, 次いで M 5 a, M 10 a,b 抢よび M 11 a,b が認められた.

\section{4. ラット肝臓中代謝物の定量}

ラットに KG-2413- ${ }^{14} \mathrm{C}$ を $1 \mathrm{mg} / \mathrm{kg}$ 経口投与 後の肝臓を, Scheme 1 に示した操作に従い溶媒 分画した. その結果を Table V に示した. 肝蔵 の非抱合体画分は, 投与後15分および60分に拈い ていずれも $40 \%$ 前後であり, 血漿あるいは尿に比 べて高い比率を示した， それに対して，抱合体画 分の占める割合が血漿あるいは尿より少なかっ
た。

次に 1 例として，投与後15分の肝臓の非抱合体 画分和よび抱合体画分の TLC-ARG の模式図を Fig. 3 に示した. 非抱合体 画分では未変化体以 外に放射性代謝物として約11種の，抱合体画分で は約 7 種のスポットが認められた.

投与後15分特よび60分の非抱合体和よび抱合体 画分中の各代謝物を定量した結果を Table VI に 示した. 非抱合体画分では, M 5 a 扎よび M 7 が多く検出され, 次いで M $5 \mathrm{~b}$ が多く認められ た. 未変化体は投与後15分では多く認められる が，60分になると急激に減少した。一方, 抱合体 画分では, M $5 \mathrm{a}$ および M $5 \mathrm{~b}$ が多く検出され た. 胡, M $10 \mathrm{a}, \mathrm{b}, \mathrm{M} 11 \mathrm{a}, \mathrm{b}$ および M $2 \mathrm{a}, \mathrm{b}$, 

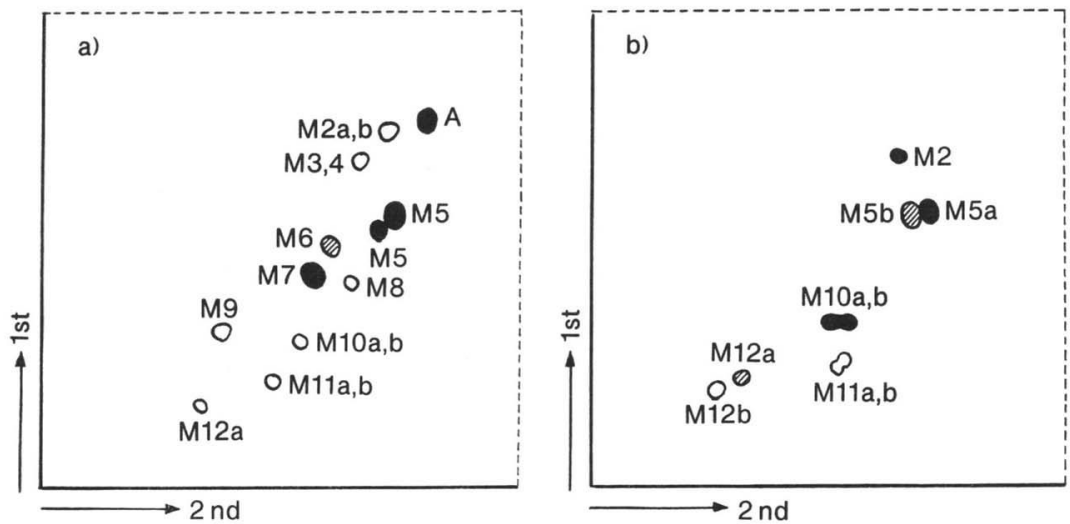

Fig. 3. Autoradiograms of the two-dimensional TLC of the metabolites extracted from the liver $15 \mathrm{~min}$ after oral administration of $\mathrm{KG}-2413-{ }^{14} \mathrm{C}$ in rats

a) Unconjugated fraction, b) Conjugated fraction

A : KG-2413 base

Table VI. Quantification of KG-2413 and its metabolites in the liver after oral administration of $\mathrm{KG}-2413-{ }^{14} \mathrm{C}$ in rats

\begin{tabular}{|c|c|c|c|c|}
\hline \multirow{3}{*}{ Metabolites } & \multicolumn{4}{|c|}{$\%$ of dose } \\
\hline & \multicolumn{2}{|c|}{$15 \mathrm{~min}$} & \multicolumn{2}{|c|}{$60 \mathrm{~min}$} \\
\hline & Unconjugated & Conjugated & Unconjugated & Conjugated \\
\hline $\mathrm{KG}-2413$ base & $0.90 \pm 0.28$ & N.D. & $0.07 \pm 0.03$ & N.D. \\
\hline $\mathrm{M} 2 \mathrm{a}, \mathrm{b}$ & $0.15 \pm 0.04$ & $1.93 \pm 0.19$ & $0.07 \pm 0.01$ & N.D. \\
\hline M3, M4 & $0.08 \pm 0.01$ & N.D. & N.D. & $\mathrm{N} \cdot \mathrm{D}$ \\
\hline M5 a & $3.44 \pm 0.40$ & $4.09 \pm 0.92$ & $0.75 \pm 0.39$ & $0.34 \pm 0.12$ \\
\hline M5 b & $0.93 \pm 0.14$ & $0.38 \pm 0.07$ & $0.27 \pm 0.13$ & $0.40 \pm 0.12$ \\
\hline M6 & $0.20 \pm 0.06$ & N.D. & $0.06 \pm 0.00$ & N.D. \\
\hline M7 & $0.68 \pm 0.28$ & N.D. & $0.66 \pm 0.22$ & N.D. \\
\hline M8 & $0.12 \pm 0.04$ & N. D. & $0.03 \pm 0.01$ & N.D. \\
\hline M9 & $0.02 \pm 0.01$ & N.D. & $0.01 \pm 0.00$ & $\mathrm{~N} \cdot \mathrm{D}$ \\
\hline M10 a , b & $0.12 \pm 0.10$ & $1.06 \pm 0.33$ & $0.03 \pm 0.01$ & $0.10 \pm 0.09$ \\
\hline M11 a, b & $0.01 \pm 0.03$ & $0.12 \pm 0.01$ & $0.04 \pm 0.01$ & $0.30 \pm 0.09$ \\
\hline M12 a & $0.06 \pm 0.04$ & $0.23 \pm 0.11$ & N.D. & N.D. \\
\hline M12 b & N.D. & $0.05 \pm 0.03$ & N.D. & $0.02 \pm 0.01$ \\
\hline
\end{tabular}

Each value represents the mean $\pm S$. D. of three animals.

N.D. : not detectable

Table VII. Excretion and fractionation of radioactivities in the $24 \mathrm{~h}$ urine after oral administration of $\mathrm{KG}-2413-{ }^{14} \mathrm{C}$ in guinea pigs

\begin{tabular}{lcccc}
\hline \hline \multirow{2}{*}{$\begin{array}{l}\text { Excretion } \\
(\% \text { of dose })\end{array}$} & \multicolumn{4}{c}{$\%$ of urine } \\
\cline { 2 - 5 } & Unconjugated & Conjugated & Acidic & Polar \\
\hline $37.3 \pm 3.2$ & $52.4 \pm 3.4$ & $10.0 \pm 1.0$ & $0.8 \pm 0.1$ & $36.8 \pm 2.8$ \\
\hline
\end{tabular}

Each value represents the mean \pm S.D. of four animals. 

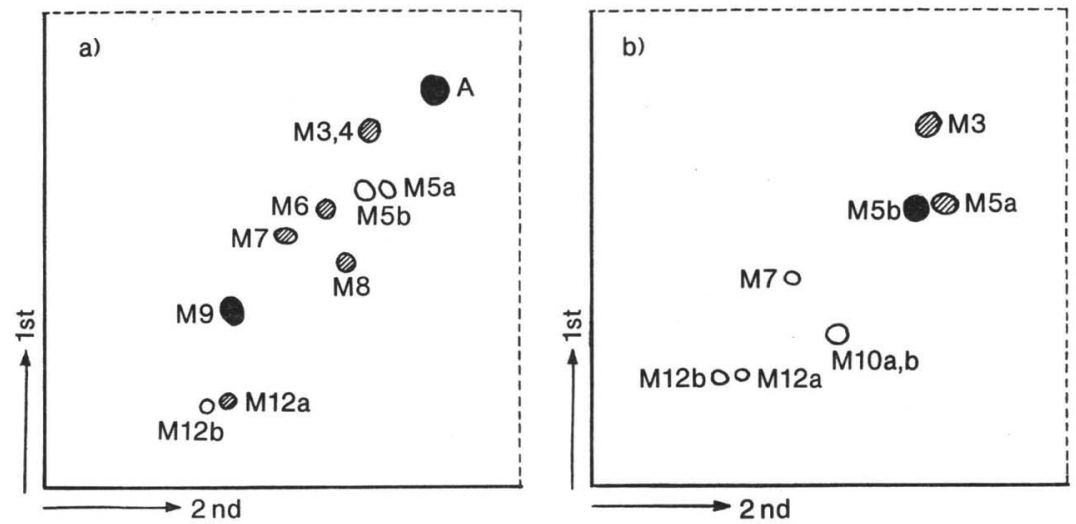

Fig. 4. Autoradiograms of the two-dimensional TLC of the urinary metabolites after oral administration of $\mathrm{KG}-2413-{ }^{14} \mathrm{C}$ in guinea pigs

a) Unconjugated fraction, b) Conjugated fraction A : KG-2413 base

Table VIII. Urinary excretion of KG-2413 and its metabolites after oral administration of $\mathrm{KG}-2413-{ }^{-14} \mathrm{C}$ in guinea pigs

\begin{tabular}{lcc}
\hline \hline \multirow{2}{*}{ Metabolites } & \multicolumn{2}{c}{ Urinary excretion (\% of dose) } \\
\cline { 2 - 3 } & Unconjugated & Conjugated \\
\hline KG-2413 base & $3.67 \pm 1.82$ & N.D. \\
M2 & N.D. & N.D. \\
M3, M4 & $0.34 \pm 0.10$ & $0.61 \pm 0.07$ \\
M5 a & $0.18 \pm 0.11$ & $0.45 \pm 0.13$ \\
M5 b & $0.43 \pm 0.23$ & $1.19 \pm 0.11$ \\
M6 & $0.56 \pm 0.22$ & N.D. \\
M7 & $0.46 \pm 0.11$ & $0.15 \pm 0.00$ \\
M8 & $0.43 \pm 0.20$ & N.D. \\
M9 & $12.63 \pm 1.15$ & N.D. \\
M10 a b & N.D. & $0.13 \pm 0.03$ \\
M11 a b & N.D. & N.D. \\
M12 a & $0.39 \pm 0.10$ & $0.13 \pm 0.01$ \\
M12 b & $0.08 \pm 0.01$ & $0.14 \pm 0.02$ \\
\hline
\end{tabular}

Each value represents the mean $\pm S$. D. of four animals.

N.D. : not detectable

M 12 b（投与後15分のみ）も比較的多く認められ た.

\section{5. モルモット尿中代謝物の定量}

モルモットに KG-2413- ${ }^{14} \mathrm{C}$ を $2 \mathrm{mg} / \mathrm{kg}$ 経口 投与後 24 時間までの尿を, ラット尿と同一の方 法 ${ }^{12)}$ で溶媒分画した。 その結果を Table VII に 示した. 24時間までの放射能の尿中排泄量は，ラ
ットと顕著な差は認められない、しかしながら， モルモットでは抱合体画分がラットの約 $1 / 5$ 程度 と少なく，尿中には主に非抱合体として排泄され た.また，極性画分もラットに比べ若干高い值を 示した。

次に，非抱合体画分括よび抱合体画分の TLCARG の模式図を Fig. 4 亿示した. 非抱合体画 分では未変化体以外に放射性代謝物として約 9 種 の, 抱合体画分では約 7 種のスポットが認められ た.

各画分中の代謝物を定量した結果をTable VIII に示した. 非抱合体では $N$-オキシド体で ある M9 が最も多く検出され，次いで未変化体が 多く認められた。一方，抱合体画分では M 5 b が多く検出され，M5 a 和よび M 3，4 も比較的 多く存在した.

\section{考 察}

$\mathrm{KG}-2413-{ }^{14} \mathrm{C}$ を $1 \mathrm{mg} / \mathrm{kg}$ 経口投与したときの ラット尿, 胆汁, 血漿および肝臓中代謝物, 特よ び $2 \mathrm{mg} / \mathrm{kg}$ 経口投与したときのモルモット尿中 代謝物の定量を行った。

ラット尿中では, M $5 \mathrm{~b}$ 抢よび M $5 \mathrm{a}$ の両水 酸化体が非抱合体および抱合体として最も多く存 在し，尿中放射能の $52 \%$ 占めた（Table I). ま た，M $12 \mathrm{~b}$ も比較的多く認められた. これに対 して, 未変化体は尿中放射能の僅か $0.4 \%$ 程度に すぎなかった。また，すでに報告したように，尿 
中代謝物の抱合体は主としてグルクロン酸抱合体 であった ${ }^{12)}$.

胆汁中では, M 5 b 抢よび M $5 \mathrm{a}$ の両水酸化 体の抱合体が，胆汁中放射能の $52 \%$ 占めた (Table II). また，胆汁抱合体画分中の代謝物は すべて水酸基を持っていることから，水酸基部分 が抱合されたものが活発に胆汁中へ排泄されると 考觉られる.

投与後15～60分に括ける血漿中では，M 5 b が 抱合体として最も多く存在し, 血漿中放射能の約 $1 / 3$ 程度を占めた (Table IV). 次いで, M 5 a と その抱合体が血墏中放射能の $9 \%$ 程度認められ た. M $5 \mathrm{a}$ と M $5 \mathrm{~b}$ の量的関係は, 尿中のそれ らの存在比 (Table I) と良く対応している. ま た，その他にも M $2 \mathrm{a}, \mathrm{b}, \mathrm{M} 3,4, \mathrm{M} 10 \mathrm{a}, \mathrm{b}$ 打よ び M $11 \mathrm{a}, \mathrm{b}$ も比較的多く認められ, さらに少量 の M7 の存在も認められた. これに対して, 未変 化体の占める割合は投与初期から僅かであり, KG-2413 は速やかに 代謝されると推擦される.

ラットに KG-2413- ${ }^{14} \mathrm{C}$ を経口投与すると, 投与 後 6 時間前後に腸肝循環に起因すると思われる第 2 のピークが認められている ${ }^{6)}$ このときの血漿 中放射能はほとんどが抱合体として存在し (Table III), そのうち M $5 \mathrm{~b}$ が抱合体として血 漿中放射能の $62 \%$ を占めた. M $5 \mathrm{~b}$ は抱合体とし て胆汁中に活発に排泄されて和り，これが腸管内 で脱抱合された後再吸収され，再び肝蔵中で抱合 化され，血漿中に出現したものと推察される。

投与後15〜60分に护ける肝臓中では，血漿中と 同様, M $5 \mathrm{a}$ と M $5 \mathrm{~b}$ 和よびそれらの抱合体が 多く認められた (Table VI). M 5 a と M 5 bの 量的関係は尿, 胆汁括よび血漿中（Table I, II および IV) とは異なり, M 5 a の方が多かった。 しかしながら，肝を用いた in vitro 代謝では， M $5 \mathrm{~b}$ の方が多く生成する15) どか M 5 b が 抱合体として肝蔵から胆汁执よび血墏中に速やか に移行するため, M 5 a の方が多く検出されたも のと考光られ、また，投与後15分では M $2 \mathrm{a}, \mathrm{b}$ 扣よび M $10 \mathrm{a}, \mathrm{b}$ も比較的多く存在するが，投与 後60分になるとこれらは減少し, M 7 や M $11 \mathrm{a}, \mathrm{b}$ の占める割合が高くなった。また，未変化体は時 間の経過に伴い急激に減少し，かつ血漿や胆汁中 に末変化体はごく僅かしか認められなかった。
以上の結果から, ラットに抏いて KG-2413 は 速やかに代謝されること, 和よびその主代謝物は ベンズイミダゾール環の 5 位または 6 位の水酸化 体およびその抱合体であり, 芳香環の水酸化がラ ットに持ける主代謝経路であることが明らかとな った.

前述のように, ラットに拈ける KG-2413 の代 謝様式として，a） ベンズイミダゾール環の水酸 化, b ） 1,4-ジアゼピン環の $N$-酸化拉よび $N-$ 脱メチル化，c） 1,4-ジアゼピン環の $\alpha$-炭素の 酸化 (ラクタム形成), 拈よびd) 側鎖の脱エチ ル化が明らかとなっており, これらの反応が単独 あるいは複合的に起こった代謝物（M1〜M 12 a， b) が尿和よび胆汁中ょり単離同定されている ${ }^{12)}$. 今回, さらにこれらの代謝物が血漿拉よび肝蔵中 にも存在することが明らかとなった.しかしなが ら， c ）の代謝様式については，KG-2413 のラ クタム型代謝物は認められていないことから, KG-2413 自身の $\alpha$-炭素は酸化されにくいか, あるいは反応が極めて遅いのではないかと推察さ れる。

一方，モルモット尿中では $N$-オキシド体であ る M9 が主代謝物であり, 未変化体も比較的多く 存在した (Table VIII). また, M 5 b 拉よび M 5 a の二種の水酸化体は主に抱合体として存在 するが，両者の和は M9 の約 6 分の 1 程度であっ た.したがって，モルモット尿で抱合体画分に比 べ非抱合体画分の割合が多かった（Table VII）

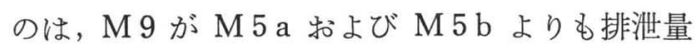
が多かったことによることが明らかとなった．モ ルモット尿中には, ラット尿中代謝物以外の新た な代謝物は認められなかったことから, 基本的に はラットと同様な代謝経路を経ると考えられる. 以上のことから，ラット执よびモルモットに拈け る KG-2413 の代謝経路は, Scheme 2 のように 推察された.

ラット拈よびモルモットの主要な代謝物の尿中 排泄率 (非抱合体十抱合体) を比較すると Fig. 5 のようになる、KG-2413を経口投与した際の尿 中主代謝物は, ラットではベンズイミダゾール環 の 5 位または 6 位の水酸化体であるが，モルモッ トでは 1,4 -ジアゼピン環の 4 位の窒素が $N$-酸 化された $N$-オキシド体であり，ラットとモルモ 


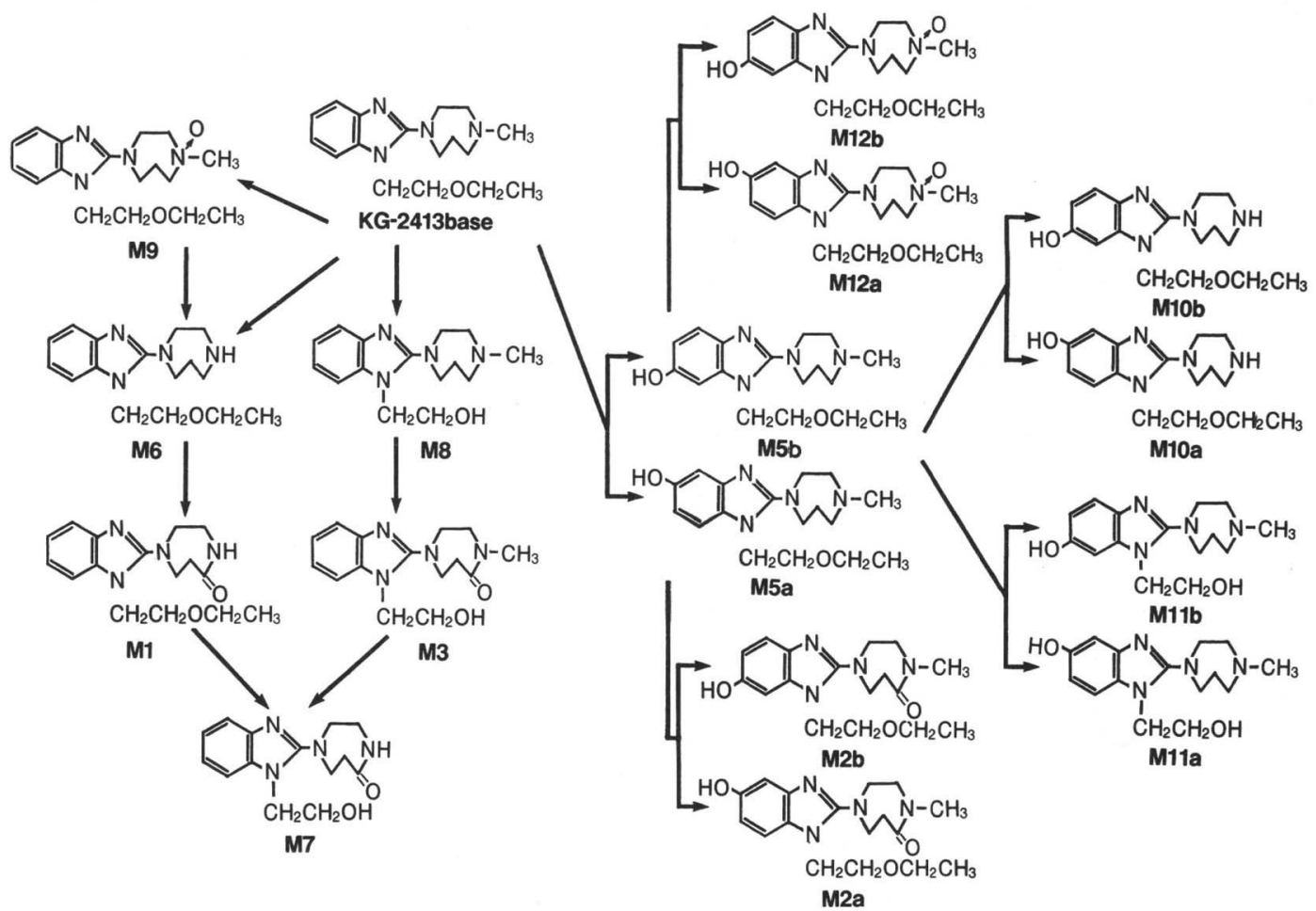

Scheme 2. Proposed metabolic pathways of KG-2413 in rats and guinea pigs $\mathrm{M} 1, \mathrm{M} 2$ and M $11 \mathrm{a}, \mathrm{b}$ were not detected in guinea pigs.

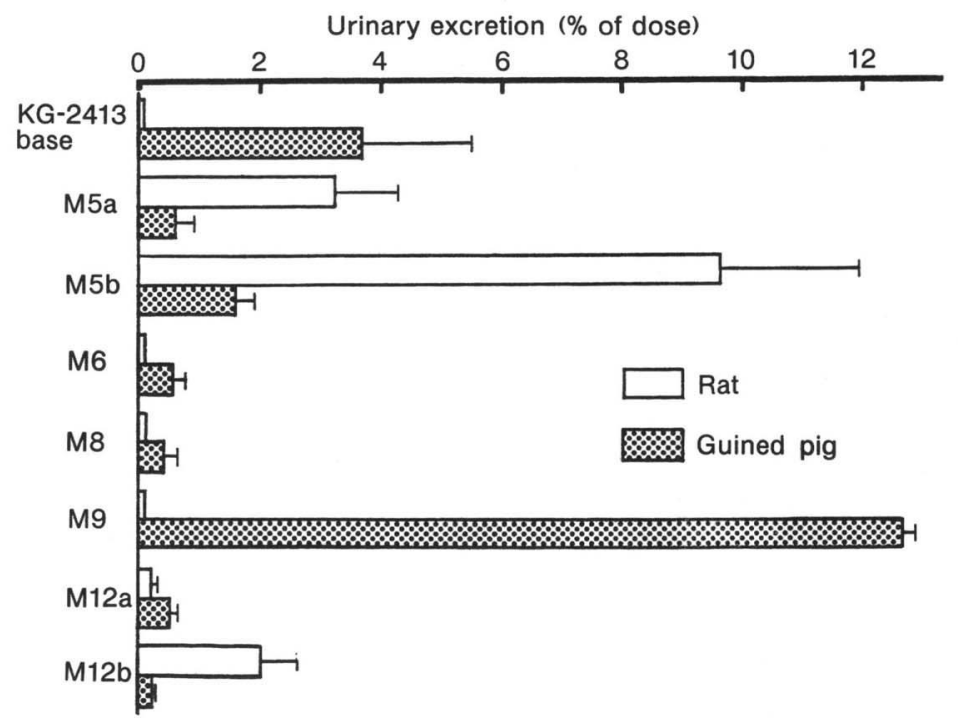

Fig. 5. Urinary excretion of KG-2413 and its main metabolites (unconjugated + conjugated) after oral administration of $\mathrm{KG}-2413-{ }^{-14} \mathrm{C}$ in rats $(1 \mathrm{mg} / \mathrm{kg})$ and guinea pigs $(2 \mathrm{mg} / \mathrm{kg})$ 
ットでは，代謝物の尿中排泄量に種差が認められ た.このらち M9は, ラットに执いて胆汁中にも 認められず，かつ尿中排泄量も極めて少ないこと から，KG-2413 の N-酸化活性が非常に弱いか,
あるいは $N$-オキシド体の還元が関与していると も考光られる．この点に関しては, in vitro 代謝 実験により検討し，別途報告する.

\section{文献}

1) Fukuda, T., Morimoto, Y., Iemura, R., Kawashima, T., Tsukamoto, G. and Ito, K. : Effect of 1-(2-ethoxyethyl)-2-(4-methyl-1-homopiperazinyl) benzimidazole difumarate (KB-2413), a new antiallergic, on chemical mediators. Arzneim. -Forsch./Drug Res., 34(II) : 801-805 (1984).

2) Fukuda, T., Saito, T., Tajima, S., Shimohara, K. and Ito, K. : Antiallergic effect of 1-(2-ethoxyethyl)-2-(4-methyl-1-homopiperazinyl) benzimidazole difumarate (KB-2413). Arzneim.-Forsch./Drug Res., 34(II) : 805-810 (1984).

3) Fukuda, T., Saito, T. and Ito, K. : Antiasthmatic effect of 1-(2-ethoxyethyl)-2(4-methyl-1-homopiperazinyl) benzimidazole difumarate (KB-2413), a new antiallergic. Arzneim.-Forsch./Drug Res., 34(II) : 811-815 (1984).

4) Fukuda, T., Saito, T., Yoshidomi, M. and Ito, K. : Influence of 1-(2-ethoxyethyl)-2-(4-methyl-1-homopiperazinyl) benzimidazole difumarate (KB-2413), a new antiallergic, on ciliary movement. Arzneim.-Forsch./Drug Res., 34(II) : 816-818 (1984).

5) Hamada, T., Kadowaki, M. and Awata, N. : Radioreceptor assay for a new antiallergic agent, 1-(2-ethoxyethyl)-2-(4-methyl-1-homopiperazinyl) benzimidazole difumarate (KB-2413), in plasma. Chem. Pharm. Bull., $35: 3329-3335$ (1987).

6) Sakai, T., Takahashi, H., Hamada, T., Awata, N. and Watanabe, J. : The biological fate of 1-(2-ethoxyethyl)-2-(4-methyl-1-homopiperazinyl) benzimidazole difumarate (KB-2413) I. Absorption and excretion after oral administration to rats and guinea pigs. Xenobio. Metabol. and Dispos., 2(2): 123-131 (1987).

7) Sakai, T., Takahashi, H., Hamada, T., Awata, N. and Watanabe, J. : The biological fate of 1-(2-ethoxyethyl)-2-(4-methyl-1-homopiperazinyl) benzimidazole difumarate (KB-2413) II. Distribution after single and multiple oral administration to rats. Xenobio. Metabol. and Dispos., 2(2) : 133-145 (1987).

8) Sakai, T., Takahashi, H., Hamada, T., Awata, N. and Watanabe, J. : The biological fate of 1-(2-ethoxyethyl)-2-(4-methyl-1-homopiperazinyl) benzimidazole difumarate (KB-2413) III. Transfer to fetus and milk in rats. Xenobio. Metabol. and Dispos., 2(2): 147-154 (1987).

9) Sakai, T., Hamada, T., Awata, N. and Watanabe, J. : Interspecies differences in pharmacokinetics of an antiallergic agent, 1-(2-ethoxyethyl)-2-(hexahydro-4methyl-1,4-diazepin-1-yl) benzimidazole difumarate (KG-2413) after intravenous administration to rats, guinea pigs and dogs. Chem. Pharm. Bull., $37: 753-756$ (1989).

10) Hamada, T., Kadowaki, M., Nakamura, Y. and Awata, N. : Determination of the antiallergic agent KB-2413 in plasma by means of capillary gas chromatography with a nitrogen sensitive detector. Chem. Pharm. Bull., $34: 1168-1171$ (1986).

11）浜田 司, 酒井孝範, 粟田則男, 渡辺 淳: 新規抗アレルギー薬 KG-2413 の実験動 物に拈ける血漿中濃度. 日本薬学会第107年会講演要旨集, p. 855 (1987).

12) 㯨田則男, 高橋秀之, 能海和宣, 酒井孝範, 浜田 司: 抗アルギー薬 1-(2-ethoxyethyl)-2-(hexahydro-4-methyl-1H-1,4-diazepin-1-yl)-1H-benzimidazole difumarate (KG-2413) のラットにお㇒子る代謝物の同定. 薬誌., $109:$ 318-328 (1989).

13) Awata, N. and Satomi, O. : Synthesis of 1-(2-ethoxyethyl)-2-(4-methyl-1-homopiperazinyl) benzimidazole difumarate $\left(\left[{ }^{14} \mathrm{C}\right] \mathrm{KG}-2413\right)$. J. Labelled Compd. Radiopharm., 24 : 331-338 (1987).

14) Iemura, R., Hori, M. and Ohtaka, H. : Syntheses of the metabolites of 1-(2ethoxyethyl)-2-(hexahydro-4-methyl- $1 H$-1,4-diazepin-1-yl)-1H-benzimidazole 
difumarate (KG-2413) and their related compounds. Chem. Pharm. Bull., 37 : 962-966 (1989).

15）和田幸雄, 浜田 司, 粟田則男 : 新規抗アレルギー薬 KG-2413 の代謝に拈ける種差. 第 2 回日本薬物動態学会年会講演要旨集, $72-73$ (1987).

\section{正誤のお知らせ}

Vol. 4, No. 4 P.459〜P.470に掲載しました鐘紡 (秼和田幸雄・他の論文に正誤がありましたので下記の 通り訂正いたします。

訂正箇所

Fig. 3 (a)の図中 M5，M5 M5a，M5b に訂正 (b)の図中 M2 を M2a, b に訂正

Scheme 2の図中 M2a，M2b を M2b， M2a

M5a, M5b を M5b, M5a

M10a, M10b M10b, M10a

M11a, M11b M11b, M11a

M12a, M12b を M12b, M12a 